\title{
DIRECTED MIGRATION OF HUMAN BONE MARROW MESENCHYMAL STEM CELLS IN A PHYSIOLOGICAL DIRECT CURRENT ELECTRIC FIELD
}

\author{
Zhiqiang Zhao, Carolyn Watt, Alexandra Karystinou, Anke J. Roelofs, Colin D. McCaig, \\ Iain R. Gibson* and Cosimo De Bari*
}

Institute of Medical Sciences, University of Aberdeen, Foresterhill, Aberdeen AB25 2ZD, UK

${ }^{*}$ Iain R. Gibson and Cosimo De Bari are equal senior authors

\begin{abstract}
At sites of bone fracture, naturally-occurring electric fields (EFs) exist during healing and may guide cell migration. In this study, we investigated whether EFs could direct the migration of bone marrow mesenchymal stem cells (BM-MSCs), which are known to be key players in bone formation. Human BM-MSCs were cultured in direct current EFs of 10 to $600 \mathrm{mV} / \mathrm{mm}$. Using time-lapse microscopy, we demonstrated that an EF directed migration of BM-MSCs mainly to the anode. Directional migration occurred at a low threshold and with a physiological EF of $\sim 25 \mathrm{mV} / \mathrm{mm}$. Increasing the EF enhanced the MSC migratory response. The migration speed peaked at 300 $\mathrm{mV} / \mathrm{mm}$, at a rate of $42 \pm 1 \mu \mathrm{m} / \mathrm{h}$, around double the control (no EF) migration rate. MSCs showed sustained response to prolonged EF application in vitro up to at least $8 \mathrm{~h}$. The electrotaxis of MSCs with either early (P3-P5) or late (P7-P10) passage was also investigated. Migration was passage-dependent with higher passage number showing reduced directed migration, within the range of passages examined. An EF of $200 \mathrm{mV} / \mathrm{mm}$ for $2 \mathrm{~h}$ did not affect cell senescence, phenotype, or osteogenic potential of MSCs, regardless of passage number within the range tested (P3$\mathrm{P} 10)$. Our findings indicate that EFs are a powerful cue in directing migration of human MSCs in vitro. An applied EF may be useful to control or enhance migration of MSCs during bone healing.
\end{abstract}

Keywords: Adult human bone marrow; mesenchymal stem cells; cell migration; tissue regeneration; direct-current electric fields; osteogenesis.

${ }^{*}$ Addresses for correspondence:

C. De Bari

Institute of Medical Sciences, University of Aberdeen Foresterhill, Aberdeen AB25 2ZD, UK

Telephone Number: +44 (0)1224 437477

E-mail: c.debari@abdn.ac.uk

I.R. Gibson

Telephone Number: +44 (0)1224 437476

E-mail: i.r.gibson@abdn.ac.uk

\section{Introduction}

Bone regeneration/repair occurs not only by the surrounding mature bone cells (e.g. osteoblasts and osteoclasts) but also by migration of bone marrow-derived mesenchymal stem cells (BM-MSCs) to sites of injury and subsequent differentiation into mature osteoblasts, thus contributing to bone regeneration (e.g. osteogenesis) (Bianco and Robey, 2001; Granero-Molto et al., 2009; Mauney et al., 2010; Reichert et al., 2010; Reichert et al., 2011). Directional migration of BM-MSCs therefore is an essential process in bone repair. Thus, understanding how directional migration of BM-MSCs is controlled is of patho-physiological and clinical importance.

Wounds generate naturally-occurring endogenous electric fields (EFs) that play a significant role in guiding cell migration by a process known as electrotaxis (McCaig et al., 2005; Nuccitelli, 2003; Reid et al., 2005; Zhao et al., 1999; Zhao et al., 2006). Similar endogenous EFs have been identified and measured in various tissues and organs in vitro and in vivo including bone, and may be important for development, regeneration and wound healing (Barker et al., 1982; Bassett and Becker, 1962; Borgens, 1984; Foulds and Barker, 1983; Hammerton et al., 1991; Levin and Verkman, 2005; Levin et al., 2006; Reid et al., 2005; Welsh, 1987; Zhao et al., 2006). Importantly, externally applied electrical stimulation, either comparable to or significantly higher than the endogenous EFs, has been shown to be an effective approach to accelerate bone healing and remodelling (Aaron et al., 2004; Bassett and Becker, 1962; Bassett et al., 1964; Brighton et al., 1981; Brighton and Pollack, 1985; Dejardin et al., 2001; Fitzsimmons et al., 1986; Hammerick et al., 2010; Hodges et al., 2003; Isaacson and Bloebaum, 2010; Lavine and Grodzinsky, 1987; Nelson et al., 2003). Thus, one effect of externally applied EFs may be to act as a cue to direct migration of BM-MSCs in bone regeneration and repair.

Many cell types including bone cells respond to applied EFs in vitro at field strengths comparable to the endogenous wound EFs in vivo. In many cases, cells such as rat osteoblasts, bovine chondrocytes, bovine aortic vascular endothelial cells, and mouse endothelial progenitor cells migrate towards the cathode (Chao et al., 2000; Ferrier et al., 1986; Li and Kolega, 2002; Ozkucur et al., 2009; Zhao et al., 2011). However, some cells including rabbit osteoclasts, human osteosarcoma cells, rabbit corneal endothelial cells, and human umbilical vein endothelial cells migrate in the opposite direction, towards the anode (Chang et al., 1996; Ferrier et al., 1986; Ozkucur 
et al., 2009; Zhao et al., 2004). These diverse responses indicate that the effects of direct current (DC) EFs on cells are cell-type and species specific. Thus, cell electrotaxis needs to be established experimentally on a case-by-case basis.

MSCs have been identified in many adult tissues including bone marrow (Pittenger et al., 1999), adipose (Zuk et al., 2002), periosteum (De Bari et al., 2001a; De Bari et al., 2006), and synovial membrane (De Bari et al., 2001b; De Bari et al., 2003; De Bari et al., 2004). They are plastic-adherent fibroblast-like cells, express CD105, CD73 and CD90, lack expression of CD45 (Dominici et al., 2006) and have single-cell inherent ability to differentiate into mesenchymal lineages including bone (Pittenger et al., 1999). Due to their ease of access and culture as well as their known osteogenic potency, MSCs are obvious candidates for bone regeneration/repair applications. So far, the migration of human bone marrow MSCs has not been characterised in detail, in particular in the presence of EFs.

Here we show that BM-MSCs respond to a weak applied EF with strong migration towards the anode. We also show that physiological levels of EF stimulation do not alter cell senescence, osteogenic potential and phenotype of MSCs, making an EF an attractive guidance cue for MSCs.

\section{Methods}

\section{Chemicals, reagents and solutions}

Dulbecco's modified Eagle's medium (DMEM), fetal bovine serum (FBS), and phosphate-buffered saline (PBS) without $\mathrm{Ca}^{2+}$ or $\mathrm{Mg}^{2+}$ were from Lonza (Slough, UK). HEPES buffer solution (HEPES), antibiotic antimycotic (AA) solution, and $0.25 \%$ trypsin-EDTA were from Invitrogen (Paisley, UK). Dexamethasone, $\beta$-glycerophosphate disodium salt hydrate, L-ascorbic acid, Alizarin Red S, propidium iodide and trypan blue were from Sigma (Gillingham, UK). $100 \mathrm{~mm}$ non-treated tissue culture dishes were from Corning (Poole, UK).

\section{Cell culture}

Adult human bone marrow-derived MSCs from 3 donors were used. MSCs from donor 1 (23 years old) were derived, after informed consent and with appropriate ethical approval, by CDB in the Laboratory for Skeletal Development and Joint Disorders, Catholic University of Leuven, Belgium. MSCs from donor 2 (48 years old) and donor 3 (60 years old) were obtained commercially from PromoCell (Heidelberg, Germany). Cells were plated at a density of 3,000 cells $/ \mathrm{cm}^{2}$ in a T75 flask and serially passaged at sub-confluence every 5-7 days at the same initial density. Cells were maintained in growth medium consisting of DMEM supplemented with $10 \%$ (v/v) FBS and $1 \%(\mathrm{v} / \mathrm{v}) \mathrm{AA}$, at $37{ }^{\circ} \mathrm{C}$ in a $5 \% \mathrm{CO}_{2}$ incubator. Cells were cryopreserved in multiple vials in liquid nitrogen at both passage 1 and passage 2 , then were thawed as needed and culture-expanded for the experiments described below. All results were from cells between passage 3 and passage 10 , as indicated.

\section{Cell migration and electrotaxis assay}

Cell motility was assayed using an electrotaxis apparatus (Song et al., 2007; Zhao et al., 2006). Cells (5,000 cells/ $\mathrm{cm}^{2}$ ) were seeded and allowed to grow for at least $24 \mathrm{~h}$ in culture chambers in DMEM [supplemented with 10 $\%(\mathrm{v} / \mathrm{v}) \mathrm{FBS}$ and $1 \%(\mathrm{v} / \mathrm{v}) \mathrm{AA}]$ at $37{ }^{\circ} \mathrm{C}$ in a $5 \% \mathrm{CO}_{2}$ incubator. Immediately before a test, medium was replaced with DMEM [supplemented with $10 \%$ (v/v) FBS and 1 $\%$ (v/v) AA] containing $25 \mathrm{mM}$ HEPES. For electric field application, a DC EF was applied through agar-salt bridges connecting silver/silver chloride electrodes in beakers of Steinberg's solution, to pools of culture medium on either side of the chamber. A roof of No. $1(0.13 \mathrm{~mm})$ cover glass was applied and sealed with silicone grease (Corning DC4). The final dimensions of the chamber, through which current was passed, were $40 \mathrm{~mm}$ x $10 \mathrm{~mm}$ x $0.2 \mathrm{~mm}$. Cells were exposed to an EF for $2-10 \mathrm{~h}$ as indicated at $37^{\circ} \mathrm{C}$ in a temperature-controlled chamber on an inverted microscope stage. Serial time-lapse images were recorded using a Nikon ECLIPSE TE2000-U microscope and Simple PCI imaging system (Hamamatsu Corporation, PA, USA).

\section{Quantification of cell migration}

Directional cell migration was quantified as directedness and migration rate by tracing the position of cell nuclei relative to their original position at $t=0$, at a frame interval of 15 min using Image J software (NIH). The directedness of migration was defined as cosine $\theta$ (Zhao et al., 2006), where $\theta$ is the angle between the EF vector and a straight line connecting the start and end position of a cell. A cell moving directly towards the anode would have a directedness of 1 ; a cell moving directly along the field lines towards the cathode would have a directedness of -1; a mean value close to 0 represents random cell movement. The cosine $\theta$ will provide a number between -1 and +1 and the average of all the separate cell events yields an average directedness index. The average directedness of a population of cells gives an objective quantification of how cells have moved in relation to the EF vector.

The trajectory speed $(\mathrm{Tt} / \mathrm{T})$ is the total length of the trajectory $(\mathrm{Tt})$ that a cell has migrated divided by the time (T). The displacement speed $(\mathrm{Td} / \mathrm{T})$ is the straight-line distance between the start and end positions of a cell (Td) divided by time (T). Displacement of the cell along the $X$ axis $(\mathrm{Dx} / \mathrm{T})$ is the projection of the cell trajectory on the $X$ axis (Dx) divided by the time (T), which represents the migration of cells along the EF vector.

\section{Cell viability}

Cell viability was assessed using the trypan blue assay. Trypan blue stains dead cells blue thus enabling the counting of viable cells. The percentage of viable cells was determined as follows: [1 - (No. of dead cell/total No. of cells)] x 100 .

\section{Senescence-associated $\boldsymbol{\beta}$-galactosidase staining}

The senescence-associated $\beta$-galactosidase (SA- $\beta$-gal) assay was performed using a $\beta$-gal staining kit (Cell Signalling, Hitching, UK) as described (De Bari et al., 2001b). Cells were plated in chamber slides and allowed to attach in growth medium. Cells were washed in PBS, fixed 
for $15 \mathrm{~min}$. at room temperature in $2 \%$ formaldehyde $/ 0.1$ $\%$ glutaraldehyde, washed in PBS, and incubated overnight in a humid chamber at $37^{\circ} \mathrm{C}$ with $\mathrm{X}$-gal staining solution. Images were acquired from a microscope, and $\beta$-galpositive senescent cells were counted and shown as a proportion of 1,000 cells assessed in three independent investigations.

\section{Flow cytometry}

Culture-expanded MSC populations were used for flow cytometry at $10^{5}$ cells/test. Test antibodies were as follows: PerCP-Cy5.5-conjugated CD45 and FITC-conjugated CD90 were from BD Pharmingen (Oxford, UK); phycoerythrin (PE)-conjugated CD105 and allophycocyanin (APC)conjugated CD73 were from eBiosciences (Hatfield, UK). Isotype-specific negative control antibodies were purchased from BD Pharmingen and eBiosciences. Data were acquired using BD FACScalibur, BD LSR II and CellQuest software. Dead cells were gated out based on propidium iodide exclusion. All flow cytometry data were analysed with FlowJo 7.6 (Tree Star Inc, Ashland, OR, USA).

\section{Osteogenesis assay}

The in vitro osteogenesis assay was performed as previously described (Karystinou et al., 2009). Briefly, immediately after EF exposure of $200 \mathrm{mV} / \mathrm{mm}$ for $2 \mathrm{~h}$, EF-treated and untreated control MSCs were trypsinised off the EF chamber and plated in 24-well plates at a density of 6,000 cells/well $\left(\sim 2 \mathrm{~cm}^{2}\right)$ for osteogenic differentiation. Each donor was plated in quadruplicate. For the first $24 \mathrm{~h}$ post-seeding, cells were cultured in growth medium. Then cells were refreshed twice a week with either osteogenic medium, consisting of growth medium supplemented with $10 \mathrm{mM} \beta$-glycerophosphate, $0.05 \mathrm{mM}$ ascorbic acid and $100 \mathrm{nM}$ dexamethasone, or growth medium alone for control. After 4 weeks, cells were rinsed twice with PBS, fixed with $100 \%$ methanol for $1 \mathrm{~h}$ at $-20{ }^{\circ} \mathrm{C}$ and covered with $2 \%$ Alizarin Red S solution ( $\mathrm{pH} 4.2)$ for 5 min. Cultures were then washed thoroughly with distilled water. Photographs were acquired using a scanner. After that, staining was dissolved by $0.5 \mathrm{~N} \mathrm{HCl}-5 \%$ sodium dodecyl sulphate (SDS). The absorbance of the solubilised stain was measured in a spectrophotometer at $415 \mathrm{~nm}$.

\section{Statistical analysis}

Data are reported as mean \pm standard error of the mean (SEM), with $n$ denoting the number of tests except in the migration assay where $n$ denotes the number of cells. Means were compared using one-way analysis of variance (ANOVA) in group comparison. Two-tailed Student's $t$-test for unpaired data was applied as appropriate. A value of $p$ $<0.05$ was considered statistically significant.

\section{Results}

\section{Migration of MSCs in response to DC EFs in vitro}

In the absence of a DC EF, cells migrated randomly with 48 $\%$ of cells moving to one side of the dish and $52 \%$ towards the other side (Fig. 1C, F; Fig. 2A). In the presence of an
EF, cells migrated towards the anode (+ve pole; Fig. 1A, A', B, B'. D, E and F). Anodal directed cell migration was voltage-dependent and was evident already at an EF as low as $25 \mathrm{mV} / \mathrm{mm}$, since directedness of migration at $25 \mathrm{mV} /$ mm was $0.18 \pm 0.04(n=243$ cells) compared with 0.00 \pm 0.06 ( $\mathrm{n}=161$ cells) for the no EF control cells $(p<0.05$, one-way ANOVA; Fig. 1F). The increased directedness of cells peaked in an EF of $300 \mathrm{mV} / \mathrm{mm}$, with a directedness of $0.61 \pm 0.04$ ( $n=142$ cells; Fig. 1F). Within total MSC populations, the percentage of cells that migrated towards the anode was $65 \%$ at $25 \mathrm{mV} / \mathrm{mm}$ and increased with higher field strengths to plateau at around $85 \%$ at EFs ranging between 200 and $600 \mathrm{mV} / \mathrm{mm}$ (Fig. 2A). In an EF of $200 \mathrm{mV} / \mathrm{mm}$ over $2 \mathrm{~h}, 15 \%$ of cells migrated towards the cathode but none of these migrated more than $60 \mu \mathrm{m}$; by contrast, $85 \%$ of cells migrated towards the anode with $38 \%$ of all cells migrating more than 60 $\mu \mathrm{m}$ (Fig. 2B). When the EF polarity was reversed after 3 $\mathrm{h}$, cells migrated towards the new anode (compare Fig. 1A, A' with 1B, B' and Fig. 1D with 1E; Supplementary video 1). Cell migration speed along the $x$ axis $(\mathrm{Dx} / \mathrm{T})$ significantly increased when exposed to EFs of $\geq 100 \mathrm{mV} /$ $\mathrm{mm}$. Trajectory migration speed $(\mathrm{Tt} / \mathrm{T})$ and displacement migration speed $(\mathrm{Td} / \mathrm{T})$ also significantly increased in EFs of $\geq 200 \mathrm{mV} / \mathrm{mm}(p<0.05$ compared with no EF control; Fig. $1 \mathrm{G})$. The increased migration speed of cells peaked in an EF of $300 \mathrm{mV} / \mathrm{mm}$, with a Tt/T of $42 \pm 1 \mu \mathrm{m} / \mathrm{h}$, close to double the no EF control migration rate $(n=142$ cells; Fig. 1G). This indicates that EFs, at physiological voltages, strongly direct MSC migration and enhance cell migration speed.

\section{Migration of MSCs in a physiological EF is passage- dependent}

MSCs were passaged serially from passage 3 (P3) to passage 10 (P10). As expected, cells (donor 1) in either early passage (i.e. P3-5) or late passage (i.e. P7 and P10) migrated randomly in the absence of a DC EF (data not shown). This observation was confirmed with cells of donor 2 and donor 3. In an EF of $200 \mathrm{mV} / \mathrm{mm}$ for $2 \mathrm{~h}$, cells at early passage (i.e. P3-5) or late passage (i.e. P7 and P10) clearly migrated towards the anode (Fig. 3A). Cells (donor 1 and 3 ) showed a significantly higher degree of directedness at low passage (P3), as compared to cells at later passages ( $p<0.05$, one-way ANOVA; Fig. 3A). Cells (donor 2) showed a similar trend for a decreased directedness at P7 and P10, although this was not statistically significant (Fig. 3A).

In the absence of a DC EF, P3 cells (donor 2) showed the fastest trajectory migration speed (Tt/T; $32 \pm 1 \mu \mathrm{m} / \mathrm{h}, n$ $=325$ cells; $p<0.05$, one-way ANOVA) and displacement migration speed $(\mathrm{Td} / \mathrm{T} ; 18 \pm 1 \mu \mathrm{m} / \mathrm{h}, n=325$ cells; $p<$ 0.05, one-way ANOVA; Fig. 3C), as compared to later passage cells. Similar results were obtained with cells of donor 3 (Fig. 3D). In an EF of $200 \mathrm{mV} / \mathrm{mm}$, cells of all three donors showed a faster migration at each passage than cells cultured in the absence of an $\mathrm{EF}(p<0.05$, Fig. 3B-D), consistent with the results shown in Fig. 1. Cells of passage 3 (donor 1) showed the fastest migration speed for both trajectory migration speed (Tt/T; $40 \pm 3 \mu \mathrm{m} / \mathrm{h}, n=$ 338 cells; $p<0.05$, one-way ANOVA) and displacement 

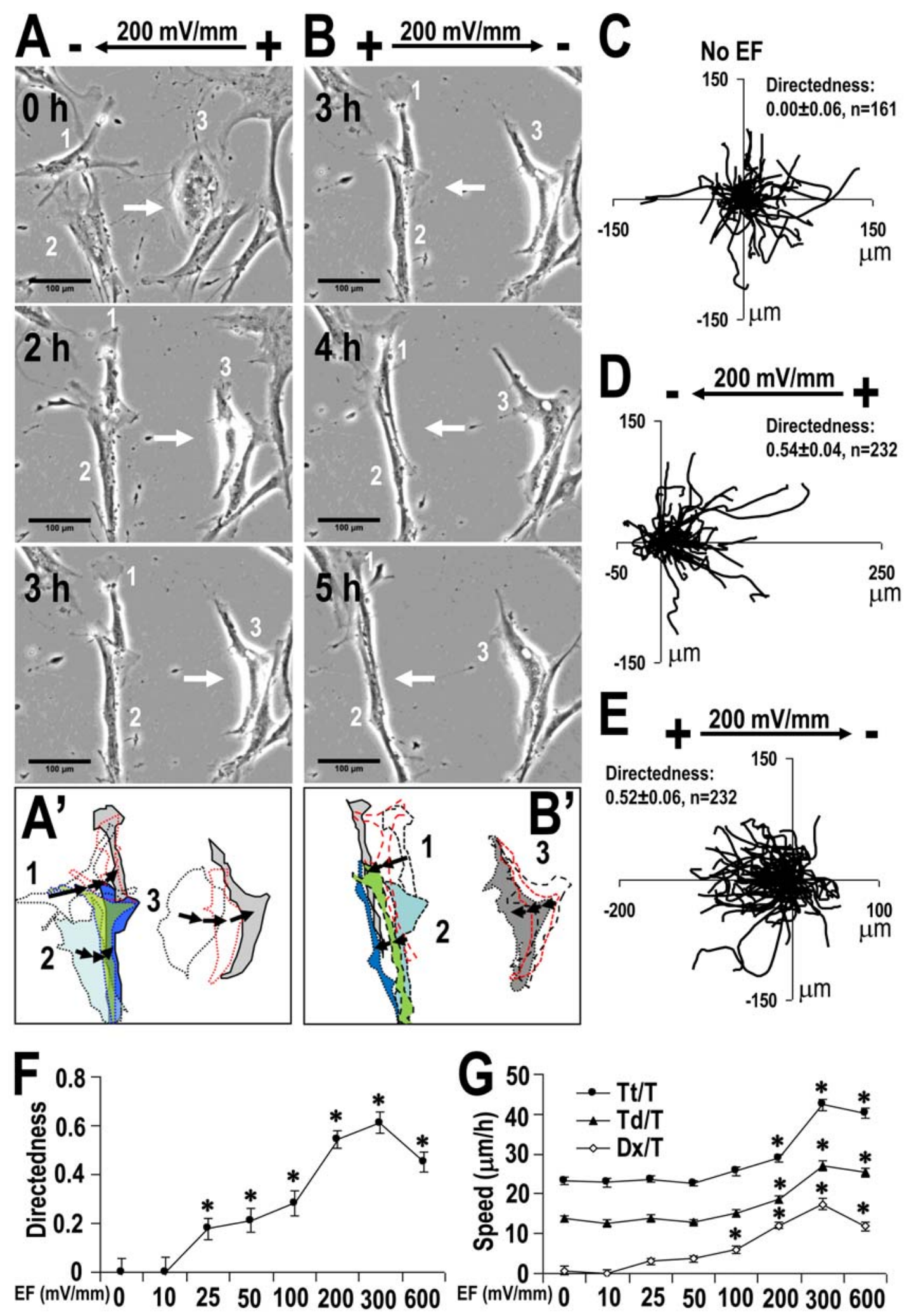

Fig. 1. MSCs migrate anodally in electric fields. (A, B) Time lapse images of MSCs (donor 1; passage 7) migrating in an EF of $200 \mathrm{mV} / \mathrm{mm}$. The polarity of the EF was reversed in (B). Arrows indicate migrating cells and direction of movement. Outlines (A' and B') of the labelled cells from 0 to $3 \mathrm{~h}$ and from 3 to $5 \mathrm{~h}$ highlight cell migration. In both panels $\mathrm{A}$ and $\mathrm{B}$, cells migrated to the anode (see also supplementary video 1). (C-E) Migrational trajectories of a population of cells over a $2 \mathrm{~h}$ period. Each line represents the migration path of a single cell with the starting point at $0 \mathrm{~h}$ positioned at the origin. (C) In the absence of an EF, cells migrate in all directions (randomly-directed). (D) An EF of $200 \mathrm{mV} / \mathrm{mm}$, and (E) reversed EF polarity of $200 \mathrm{mV} / \mathrm{mm}$. In both $\mathrm{D}$ and E cells show strong anodal migration. $x$ - and $y$-axes give distance in $\mu \mathrm{m}$. Cell migration directedness is indicated in the upper right or left corner. (F, G) Directedness of cell migration $(F)$ and migration speeds $(G)$ in response to DC EFs of increasing strength. Tt/T, trajectory speed; $\mathrm{Td} / \mathrm{T}$, displacement speed; Dx/T, $x$-axis displacement speed. Data are shown as mean $\pm \mathrm{SEM}$ of three independent experiments. ${ }^{*}, p<0.05$. Scale bar, $100 \mu \mathrm{m}$. 


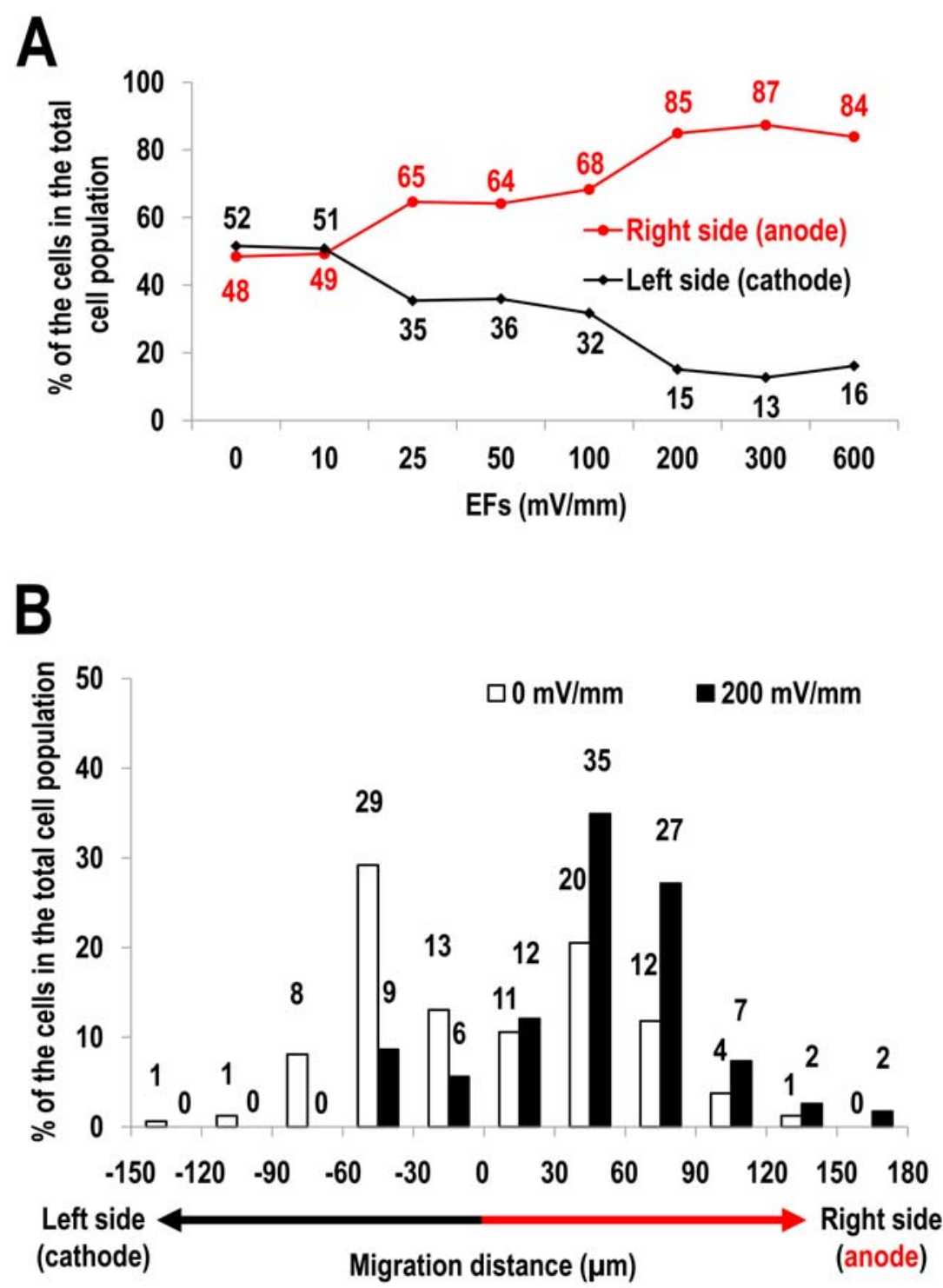

Fig. 2. MSCs migrated anodally in EFs. (A) Percentages of the cells in the total cell population that migrated towards either the right side of the dish (anode) or the left side of the dish (cathode). The data were from all of the recorded visual fields, and all cells in the visual fields were included in the analysis. No cell was stationary in these $2 \mathrm{~h}$ studies, with or without the EF. (B) Percentages of the cells that migrated over distances either in no EF control or in an EF of $200 \mathrm{mV} / \mathrm{mm}$, with arbitrary groupings of 0-30, 30-60, 60-90 $\mu \mathrm{m}$ etc. Cells that migrated towards the left side have a minus value of distance.

migration speed $(\mathrm{Td} / \mathrm{T} ; 28 \pm 2 \mu \mathrm{m} / \mathrm{h}, n=338$ cells; $p<0.05$, one-way ANOVA; Fig. 3B). Similar results were obtained with cells of donor 2 and 3 (Fig. 3C and D). These results show that MSCs respond to a DC EF of $200 \mathrm{mV} / \mathrm{mm}$ with a directional migration that is passage dependent. These results also show that cell migration speed in the absence of directional cues is passage dependent. This further confirms that EFs are a physiological cue which directs MSC migration and increases cell migration speed.

\section{Viability and cell senescence of MSCs after EF}

To verify that MSCs were not damaged by applied DC EFs, the viability of cells (three different donors) following a $2 \mathrm{~h}$ culture exposed to an EF of $200 \mathrm{mV} / \mathrm{mm}$ was compared with that of cells cultured for $2 \mathrm{~h}$ under similar conditions but without an EF. The percentage of viable cells as assessed by trypan blue dye exclusion ( $~ 90-95$ $\%$; $n=3$; Fig. 4A) and cell yield data (not shown) were similar between the groups ( $p>0.05$, one-way ANOVA). The viability of cells (donor 1; passage 7 ) following a $2 \mathrm{~h}$ culture of $600 \mathrm{mV} / \mathrm{mm}$ was also checked. The percentage of viable cells ( $\sim 90-95 \% ; n=3$; Fig. 4B) and cell yield (Fig. 4C) were similar compared with the group of cells cultured for $2 \mathrm{~h}$ under similar conditions but without an $\mathrm{EF}$, and with that of cells prior to EF stimulation $(0 \mathrm{~h})(p>$ 0.05 , one-way ANOVA). This suggests that the application of either $200 \mathrm{mV} / \mathrm{mm}$ or $600 \mathrm{mV} / \mathrm{mm}$ for $2 \mathrm{~h}$ did not result in any measured damage to the cells. Application of EFs is 

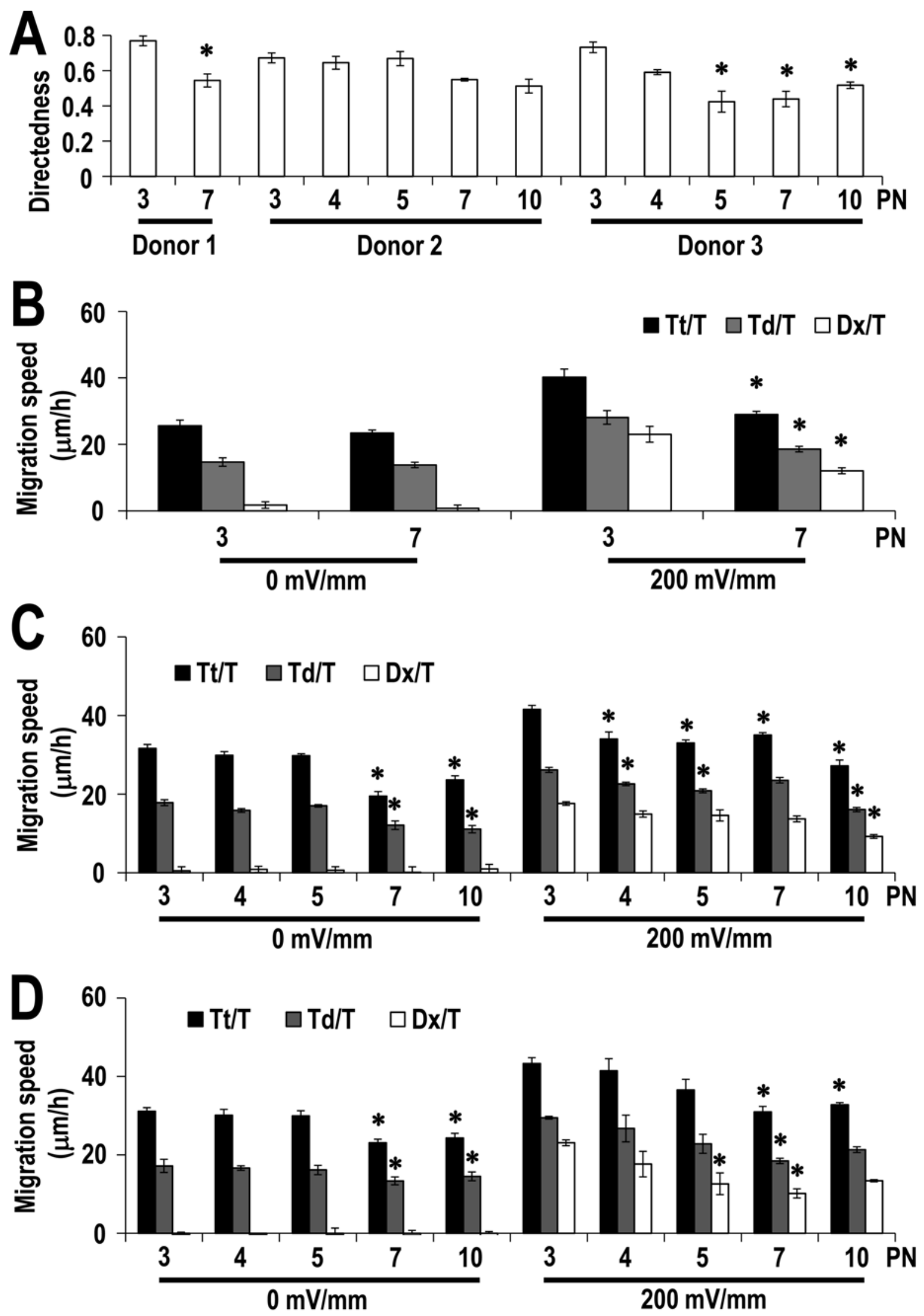

Fig. 3. Migration of MSCs at different passages in an EF of $200 \mathrm{mV} / \mathrm{mm}$. (A) Directedness of migration of MSCs (donors 1-3) at different passages in an EF of $200 \mathrm{mV} / \mathrm{mm}$. The anodal directedness of cell migration in general decreased with passage number. (B-D) Migration speeds of donor 1 (B), donor 2 (C) and donor 3 (D). Tt/T, trajectory speed; Td/T, displacement speed; Dx/T, $x$-axis displacement speed. Data are shown as mean $\pm \mathrm{SEM}$ of three independent experiments. Migration speeds declined with passage number and this occurred in control and EF-exposed cells. *, $p<0.05$, as compared to cells at passage 3. PN, passage number. 


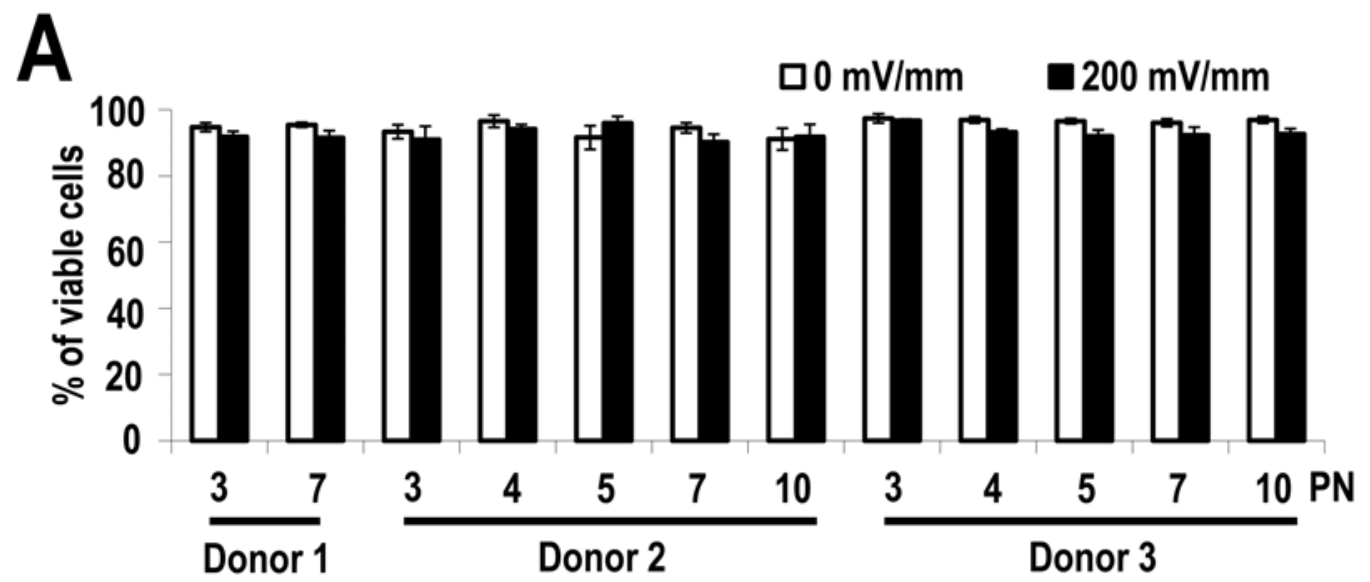

B
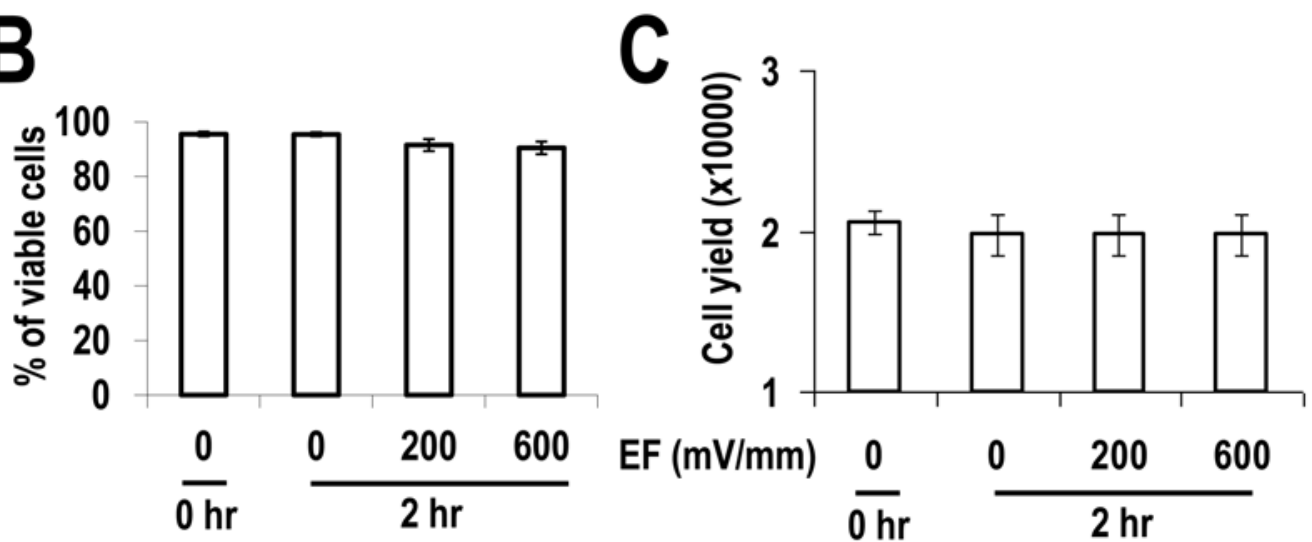

Fig. 4. Viability and yield of MSCs following application of EFs. MSCs $\left(20,000 / 4 \mathrm{~cm}^{2}\right)$ were cultured in EF chambers on plastic overnight (without EFs). (A) Percentage of viable cells with multiple donors. (B) Percentage of viable cells. (C) Cell yield. Data are shown as mean \pm SEM of three independent experiments. Cell yield and cell viability were not affected by EF exposure and did not vary between donors. PN, passage number.

therefore not responsible for the loss of migration potency in late passage MSCs. Hence, we investigated cell intrinsic factors.

Cell senescence was checked by staining MSCs (donor 1 ) for SA- $\beta$-gal. In conditions with no applied EF, $4 \%$ of cells were $\beta$-gal positive at passage 3 , while $7 \%$ of cells were $\beta$-gal positive at passage 7 . Similar results were obtained after application of an EF of $200 \mathrm{mV} / \mathrm{mm}$. Both showed statistical difference (Fig. 5). However, no significant differences were observed between cells with or without EF application at early passage (e.g. passage 3 ) or late passage (e.g. passage 7) (Fig. 5I). This indicates that an $\mathrm{EF}$ of $200 \mathrm{mV} / \mathrm{mm}$ does not affect cell senescence of MSCs, and suggests that cells becoming senescent could be a reason why MSCs lose migration potency at late passage, regardless of EF application.

\section{Migration of MSCs in response to prolonged EF stimulation}

To investigate whether the viability and migratory response of MSCs observed in an applied EF for $2 \mathrm{~h}$ (Figs 1 and 4) are maintained over a prolonged period of EF stimulation, MSCs (donor 2; passage 6) were cultured in an EF of 200 $\mathrm{mV} / \mathrm{mm}$ for $10 \mathrm{~h}$ (Fig. 6). Without an EF, as expected, cells migrated randomly (data not shown). MSCs migrated towards the anode in response to an EF of $200 \mathrm{mV} / \mathrm{mm}$ in $10 \mathrm{~h}$ culture with directedness of $0.52 \pm 0.06(n=100$ cells) at the first $2 \mathrm{~h}$. The directedness of response lasted $8 \mathrm{~h}$. After that, the response dropped off to nearly half of that observed over the initial $2 \mathrm{~h}$ period with directedness of $0.29 \pm 0.06$ ( $n=100$ cells) at the fifth $2 \mathrm{~h}$ period (Fig. $6 \mathrm{~A})$. In the absence of an EF, cells migrated at a speed of $30 \pm 2 \mu \mathrm{m} / \mathrm{h}(\mathrm{Td} / \mathrm{T} ; n=100$ cells) and $17 \pm 2 \mu \mathrm{m} / \mathrm{h}(\mathrm{Tt} / \mathrm{T} ; n$ $=100$ cells) at the first $2 \mathrm{~h}$, and this lasted $8 \mathrm{~h}$. After this time, the migration speed dropped to $25 \pm 1 \mu \mathrm{m} / \mathrm{h}$ (Td/T; $n=100$ cells $)$ and $13 \pm 1 \mu \mathrm{m} / \mathrm{h}(\mathrm{Tt} / \mathrm{T} ; n=100$ cells $)$ at the fifth $2 \mathrm{~h}$. In an EF of $200 \mathrm{mV} / \mathrm{mm}$, cells migrated at a speed of $35 \pm 2 \mu \mathrm{m} / \mathrm{h}(\mathrm{Td} / \mathrm{T} ; n=100$ cells $)$ and $22 \pm 1 \mu \mathrm{m} / \mathrm{h}(\mathrm{Tt} / \mathrm{T}$; $n=100$ cells) at the first $2 \mathrm{~h}$. The migration speed peaked at the second $2 \mathrm{~h}$ slot with a speed of $37 \pm 2 \mu \mathrm{m} / \mathrm{h}(\mathrm{Td} / \mathrm{T}$; $n=100$ cells) and $24 \pm 1 \mu \mathrm{m} / \mathrm{h}(\mathrm{Tt} / \mathrm{T} ; n=100$ cells $)$. This migration speed was significantly increased by EFs at the second $2 \mathrm{~h}$ slot compared to that of cells in no EFs in the same time point. After $6 \mathrm{~h}$, the migration speed dropped off to $25 \pm 1 \mu \mathrm{m} / \mathrm{h}(\mathrm{Td} / \mathrm{T} ; n=100$ cells $)$ and $16 \pm 1 \mu \mathrm{m} / \mathrm{h}(\mathrm{Tt} / \mathrm{T}$; $n=100$ cells) at the fourth $2 \mathrm{~h}$ (Fig. 6B). This suggests that MSCs are able to respond to prolonged application of 200 $\mathrm{mV} / \mathrm{mm}$ in culture. 

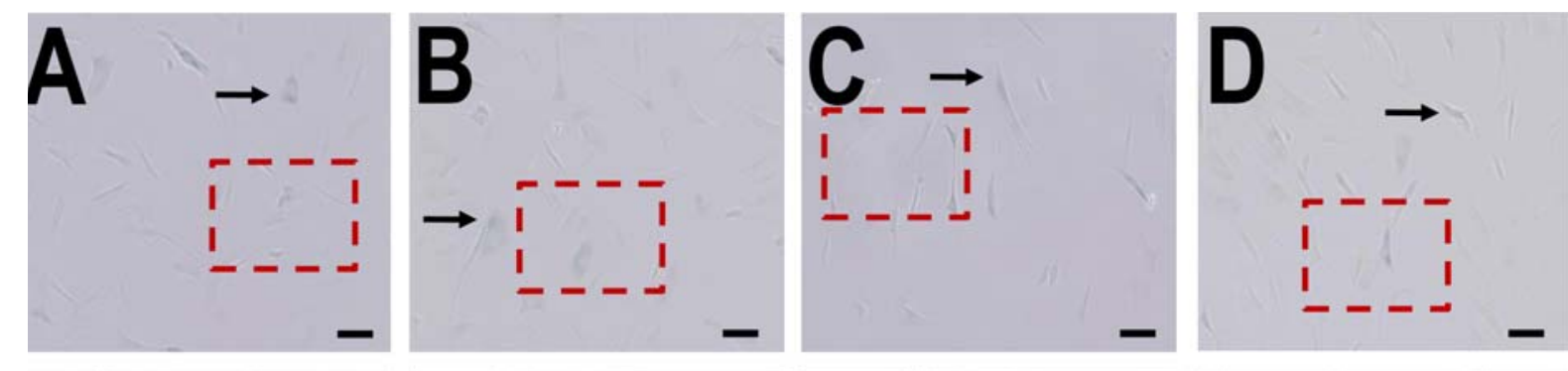

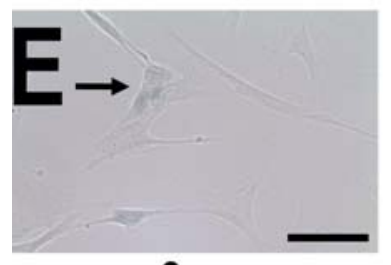

3

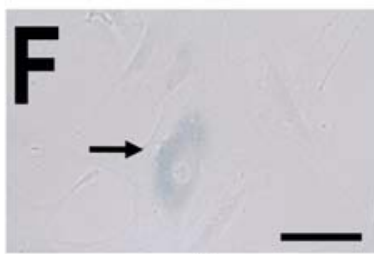

7

No EF

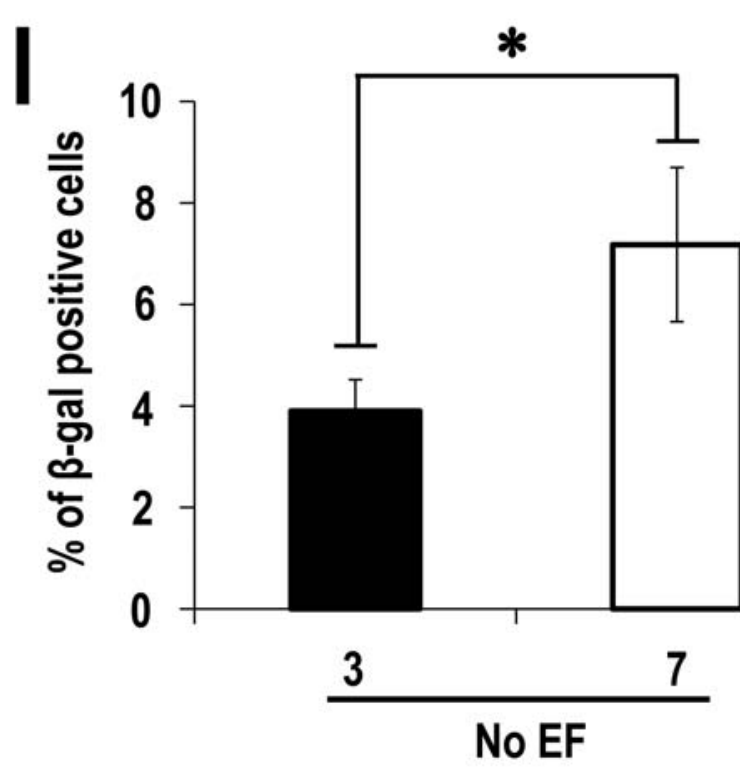

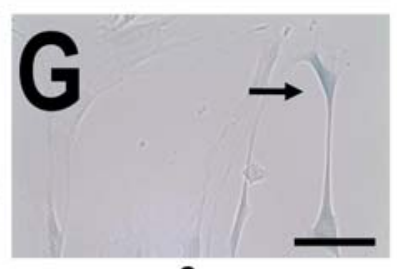

3

$200 \mathrm{mV} / \mathrm{mm}$

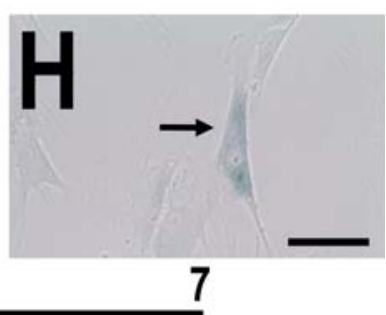

\section{7}

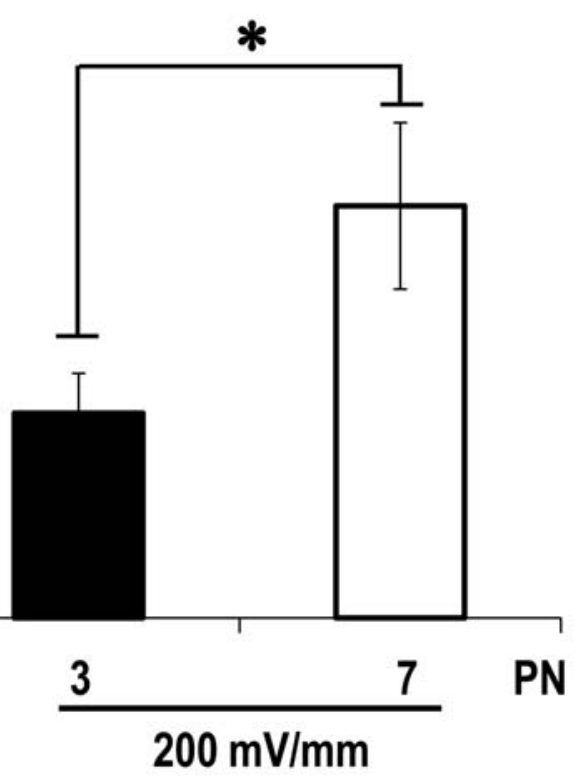

Fig. 5. Senescence associated $\beta$-gal assay. (A-D) Images of $\beta$-gal stained cells in 10x objective lens. (E-H) Images of $\beta$-gal stained cells in the boxed area in 40x objective lens. Arrow, positive cells. Scale bar, $100 \mu \mathrm{m}$. (I) Percentage of $\beta$-gal staining positive cells. Data are shown as mean $\pm \mathrm{SEM}$ of triplicates. EF exposure did not affect cell senescence.

\section{Phenotype and osteogenic differentiation of MSCs after EF application}

To evaluate the phenotype of MSCs after exposure to an EF, flow cytometry analysis was performed for conventional MSC markers. In the absence of EFs, as expected, MSCs were negative for the haematopoietic cell marker CD45 and displayed variable expression of the MSC-positive markers CD73, CD90 and CD105 (Fig. 7A). Immediately after an EF of $200 \mathrm{mV} / \mathrm{mm}$ for $2 \mathrm{~h}$, MSCs showed similar expression of the 4 markers compared with no EF control (Fig. 7A), with no obvious differences observed when compared with untreated MSCs.

Next, the osteogenesis assay was performed to evaluate the ability of MSCs to undergo osteogenic differentiation after experiencing an EF for $2 \mathrm{~h}$. MSCs (donor 1, passages $3,5,7$ and 10) were cultured either in the absence of EFs or in an EF of $200 \mathrm{mV} / \mathrm{mm}$ for $2 \mathrm{~h}$. After that, cells were cultured in osteogenic medium for 4 weeks. Both in the absence and presence of EF, MSCs responded to osteogenic treatment in monolayers as assessed by Alizarin Red $\mathrm{S}$ staining for calcium (Fig. 7B). Under the experimental conditions used, untreated cells did not show any calcium deposition with no EF or a DC EF of $200 \mathrm{mV} / \mathrm{mm}$ for $2 \mathrm{~h}$ (Fig. 7B), while treatment with osteogenic medium resulted in calcium deposition ( $p<0.05$; $t$-test; Fig. 7B, C). Alizarin red staining and calcium deposition did not differ between EF-treated and untreated MSCs ( $p>0.05$; $t$-test; Fig. 7C). Under treatment with osteogenic medium, either in the absence of EFs or in an EF of $200 \mathrm{mV} / \mathrm{mm}$, the calcium deposition of cells at passage 10 was decreased compared with that of cells at passage 3 ( $p<0.05$; $t$-test; Fig. 7C). These results confirm the MSC nature of the cells 

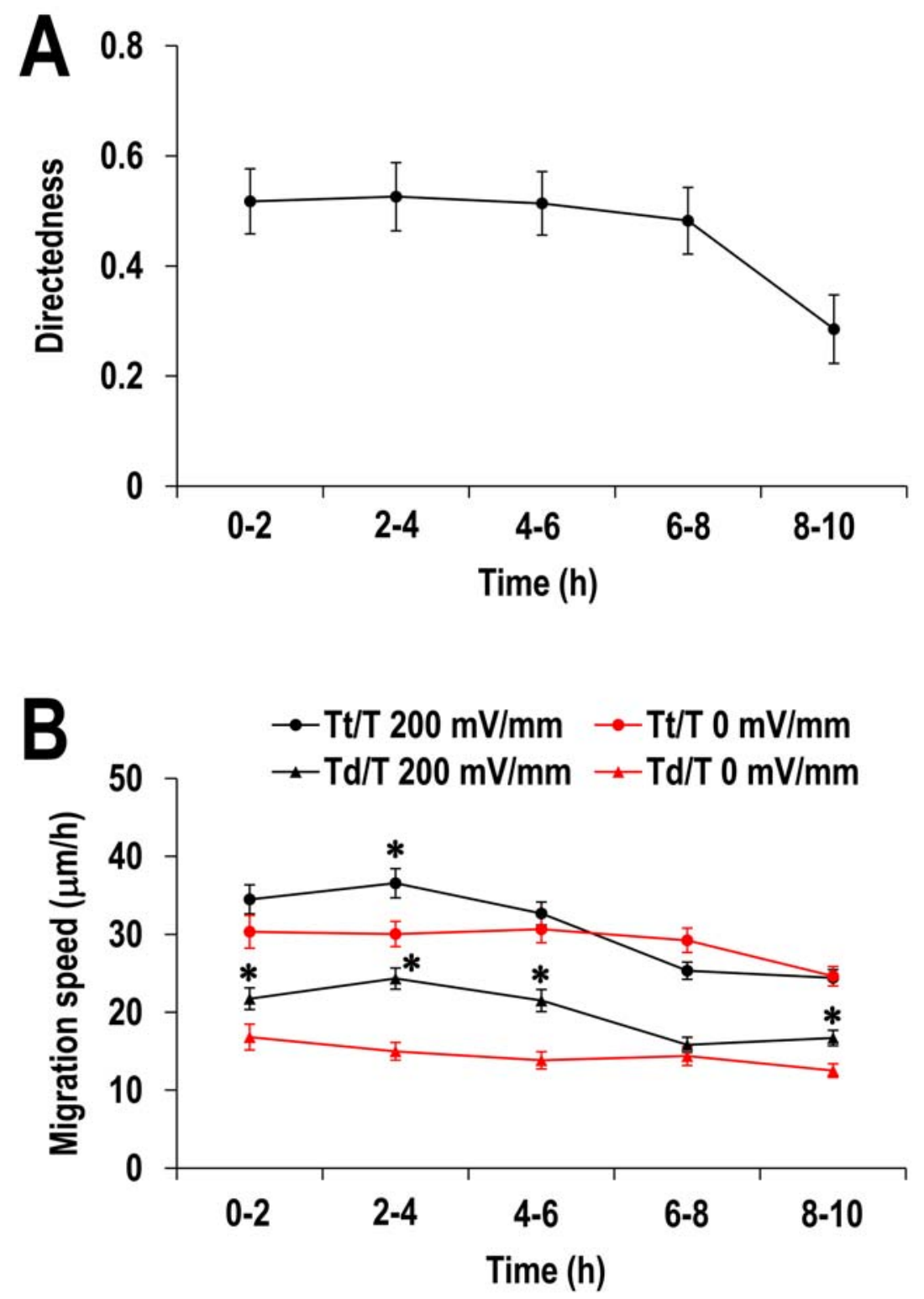

Fig. 6. Migration of MSCs in an EF of $200 \mathrm{mV} / \mathrm{mm}$ for $10 \mathrm{~h}$. (A) Directedness of cell migration every $2 \mathrm{~h}$. (B) Migration speeds every $2 \mathrm{~h}$. Tt/T, trajectory speed; Td/T, displacement speed. Data are shown as mean $\pm \mathrm{SEM}$ of three independent experiments. Anodally-directed migration was maintained for $10 \mathrm{~h}$ in culture. The rate of cell migration decreased with time in culture, both in control and EF-exposed cells. ${ }^{*}, p<0.05$.

used in this study and also suggest that EFs do not alter the phenotype and osteogenic potency of MSCs.

Supplementary Video 1 (AVI Movie format). A DC EF directs migration of MSCs. Time-lapse video corresponding to Fig. $1 \mathrm{~A}$ and $\mathrm{B}$ shows that cells migrate directionally towards the anode to the right. Reversal of the EF reversed the directional cell migration to the new anode, to the left. The recording time is $6 \mathrm{~h}$ with a frame interval of $10 \mathrm{~min} . \mathrm{EF}=200 \mathrm{mV} / \mathrm{mm}$.

(download file from paper web page: http://www. ecmjournal.org/journal/papers/vol022/vol022a26.php).

\section{Discussion}

With the aims of understanding human bone marrow derived-MSC migration and developing a novel technique to facilitate a stem cell-based therapy in bone regeneration and repair, we analysed the migration of MSCs in the absence of directional stimuli and in the presence of a DC EF ranging from a low physiological level to higher than physiological levels. We report novel effects of applied EFs on adult human bone marrow-derived MSCs from multiple donors. We observed that: 1) MSCs migrated strongly directionally towards the anode, with even a small EF inducing significant directional migration $(<25 \mathrm{mV} / \mathrm{mm})$, and that anodal-directed cell migration increased markedly 

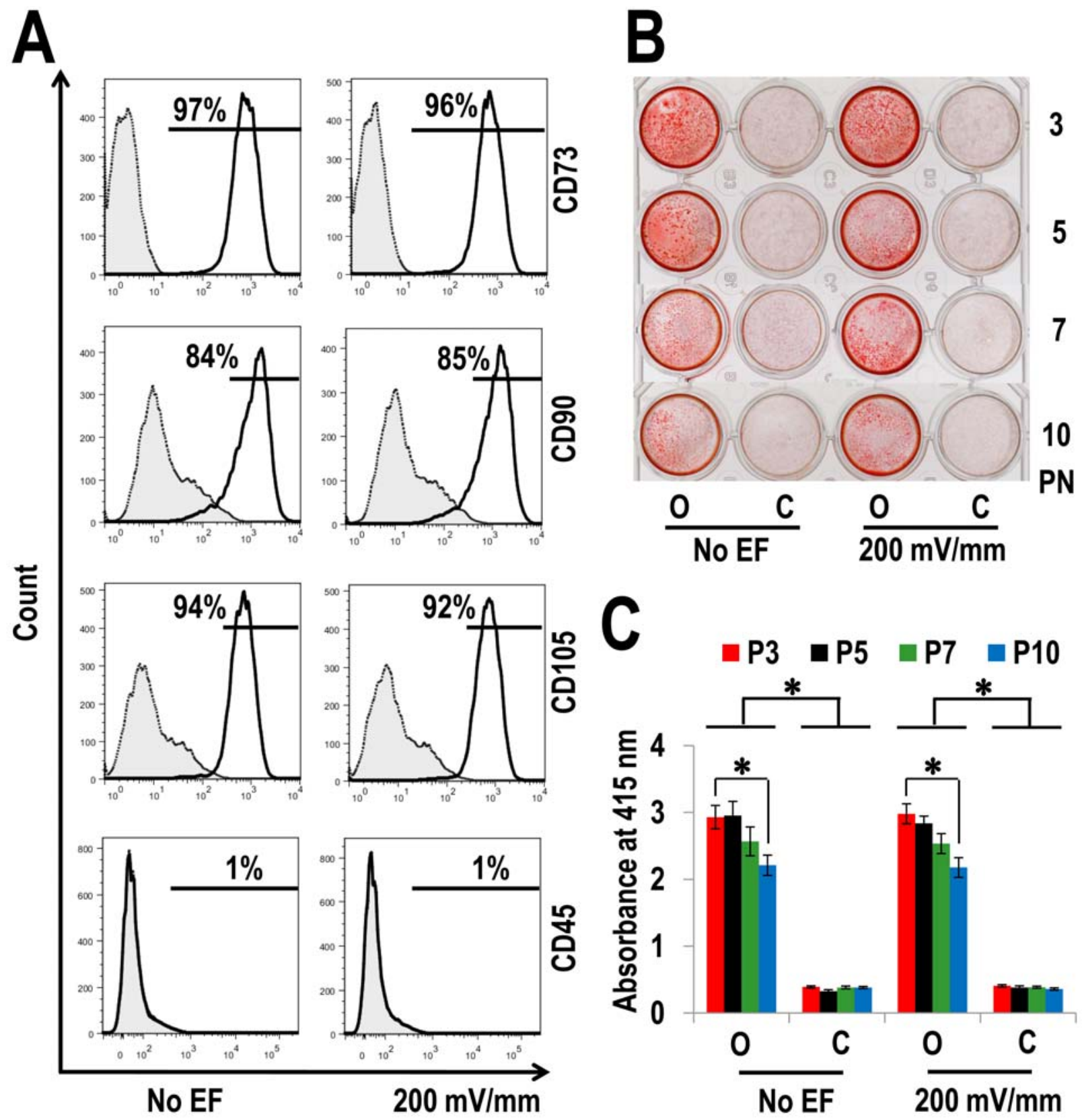

Fig. 7. Phenotype and osteogenic potency of MSCs. (A) Histograms show the expression of CD45, CD73, CD90 and CD105 in control cells and EF-exposed cells $(200 \mathrm{mV} / \mathrm{mm}$ for $2 \mathrm{~h}$ ). The $x$-axis represents the mean fluorescence intensity, and the $y$-axis represents the cell number. Shaded histograms represent the isotype controls. Horizontal line shows positive cells. For each marker tested, values are shown as mean value of the percentage of positive cells for the 3 tests. The data indicate that there was no change in the phenotype of cells as a result of EF exposure. (B) Image of Alizarin Red S-stained cells. Staining is used to measure calcium deposition. PN, passage number. (C) Quantitation of calcium deposition. O, osteogenic medium; C, growth medium as a control. P3, passage 3; P5, passage 5; P7, passage 7; P10, passage 10. Data are shown as mean \pm SEM of triplicates. EF exposure did not affect calcium deposition from cells. ${ }^{*}, p<0.05$.

as a function of increasing EF strength (up to $300 \mathrm{mV} /$ $\mathrm{mm})$; 2) MSCs from all three donors tested responded to an applied EF with directional migration towards the anode; 3) the DC EF strengths did not cause any significant damage to MSCs; 4) a DC EF of $200 \mathrm{mV} / \mathrm{mm}$ did not affect cell senescence; 5) cells were able to respond to an applied EF in prolonged culture; 6) a DC EF of $200 \mathrm{mV} / \mathrm{mm}$ did not affect the phenotype or the osteogenic potential of MSCs.

\section{Migration of MSCs in EFs}

Stem cell-based osteogenesis is of great clinical potential for patients suffering from bone injury, cancer and dysplasia. However, problems of homing stem cells to the target tissues and integrating stem cells within target sites still exist, which prevent or weaken the effect of therapy (De Bari et al., 2003; Fernandez-Tresguerres-HernandezGil et al., 2006; Fong et al., 2011). Several biochemical 
and biophysical methods to direct migration of stem cells have been explored to address these difficulties. The biochemical explorations include genetic manipulation of chemokines and their receptors such as CXCL12/CXCR-4 and stimulation of matrix metalloprotease, which enhances chemotaxis and migration of stem cells (Fong et al., 2011; Miller et al., 2008; Suzuki et al., 2006). A magnetic field as a biophysical method of cell guidance/homing has been shown to direct the migration of neural stem cells (Song et al., 2010). We have investigated the role of EFs in directing the migration of MSCs, and provide evidence that physiological EFs robustly direct and speed MSC migration towards the anode.

DC EFs are present naturally at wounds in a variety of different tissues and are a powerful directional guidance cue for epithelial cells, fibroblasts, vascular endothelial cells, keratinocytes, endothelial progenitor cells, and neurons (McCaig et al., 2005; McCaig et al., 2009; Robinson and Messerli, 2003; Trollinger et al., 2002; Yao et al., 2009; Zhao et al., 1996; Zhao et al., 2004; Zhao et al., 2006; Zhao et al., 2011). Directed migration of cells in a DC EF is highly cell-type specific, since some cell types migrate cathodally and others anodally (Robinson, 1985). Here, adult human bone marrow-derived MSCs showed strong anodal electrotaxis in physiological EFs, and this migration response increased with increasing EF strength between $25-300 \mathrm{mV} / \mathrm{mm}$. Human induced pluripotent stem cell (hiPS) also show anodal electrotaxis in physiological EFs (Zhang et al., 2011). However, mouse adipose-derived stromal cells (mASC) migrated towards the cathode in response to EFs (Hammerick et al., 2010). In our lab, rat bone marrow-derived MSCs migrated towards the cathode in an EF of $200 \mathrm{mV} / \mathrm{mm}$ (unpublished data). There are two important differences in electrotaxis response between cells from human and those from rat or mouse. The first difference is that human MSCs and hiPS migrated anodally, while mASCs and rat MSCs migrated in the opposite direction, cathodally, at similar EF strengths. Mature bone cells also show similar differences. Rat osteoblasts migrated towards the cathode (Ferrier et al., 1986; Ozkucur et al., 2009). However, in our hands, human osteoblasts migrated anodally (data not shown). The second difference is that without an EF, human MSCs and hiPS migrated rapidly with a trajectory migration speed of $\sim 25 \mu \mathrm{m} / \mathrm{h}$ (donor 1; passage 3) and $\sim 16$ $\mu \mathrm{m} / \mathrm{h}$; while mASCs migrated slowly at only $\sim 0.7 \mu \mathrm{m} / \mathrm{h}$. In an EF of $200 \mathrm{mV} / \mathrm{mm}$, the migration speed of human MSCs and hiPS was increased to $\sim 40 \mathrm{~m} / \mathrm{h}$ (donor 1; passage 3 ) and $\sim 21 \mu \mathrm{m} / \mathrm{h}$, respectively; while in a high EF strength of $600 \mathrm{mV} / \mathrm{mm}$, mASC migration speed was increased only to $\sim 3.5 \mu \mathrm{m} / \mathrm{h}$. These differences in electrotaxis could be related to differences in cell types, tissue sources and species, thereby emphasising the need for comprehensive studies of the effects of EF application on a case-by-case basis. The underlying mechanisms of MSC electrotaxis for each cell type need to be clarified.

It is especially interesting that human bone marrow MSCs showed significant anodally-directed guidance even at a very low and physiological EF strength of $\sim 25 \mathrm{mV} / \mathrm{mm}$. We tested an even lower EF strength $(10 \mathrm{mV} / \mathrm{mm})$ at which cells did not show anodal-directed migration. Thus, we confirmed that the threshold to induce directional migration of human bone marrow MSCs lies between 10 and $25 \mathrm{mV} /$ $\mathrm{mm}$. There are many advantages to using low voltages for EF stimulation. The most important ones for developing a practical technique of EF application is that this will significantly prevent electro-chemical product generation (from electrodes), the generation of heat, and effects on other cell types in 3D tissues (McCaig et al., 2005; Zhang et al., 2011). This will also allow more prolonged application in clinical practice. In our study, an EF of $25 \mathrm{mV} / \mathrm{mm}$ is lower than the thresholds for the electrotaxis of endothelial progenitor cells and endothelial cells (Zhao et al., 2004; Zhao et al., 2011). Thus, this would allow selective directed migration of MSCs whilst potentially avoiding effects on endothelial progenitor cells and endothelial cells.

Increasing the field strength increased the anodal directedness of MSCs and this directedness peaked at 200$300 \mathrm{mV} / \mathrm{mm}$. This field strength range can be regarded as physiological, although slightly higher than the strength of endogenous wound EFs ( 42-100 $\mathrm{mV} / \mathrm{mm}$ ) (Barker et al., 1982; Chiang et al., 1992). Our findings also indicate that application of either $200 \mathrm{mV} / \mathrm{mm}$ or $600 \mathrm{mV} / \mathrm{mm}$ for $2 \mathrm{~h}$ did not damage the cells. MSCs were able to respond to a DC EF for a prolonged duration of EF application. The cell phenotype and osteogenic potency were not altered by a DC EF. Our studies therefore indicate that adult human bone marrow-derived MSCs, which are attracting attention for tissue engineering and regenerative therapy, show robust directional migration and faster migration speed in a physiological DC EF. A very small EF $(25 \mathrm{mV} / \mathrm{mm})$ can be an effective cue to induce and guide migration of MSCs.

\section{Migration and senescence of MSCs in vitro}

The engineering of cell-based biological bone substitutes often requires large numbers of stem cells, thus raising a need for in vitro culture expansion. In this study, we expanded human bone marrow-derived MSCs of 3 donors and showed that the serially passaged MSCs exhibited progressive loss of migratory potential, either in the absence of directional cues or in the presence of a DC EF of $200 \mathrm{mV} / \mathrm{mm}$. Alizarin Red S staining showed that MSCs at passage 10 exhibited a reduced osteogenic potential compared to earlier passages, either in an EF or in no EF. The SA- $\beta$-gal staining of MSCs showed more positive cells at passage 7 than at passage 3, either in the absence of directional cues or in the presence of an EF of $200 \mathrm{mV} / \mathrm{mm}$. Our results also indicate that a DC EF does not damage the cells and does not affect cell senescence. Therefore, application of EFs does not cause cells to lose migratory potency, nor results in a low osteogenic potential; instead, cells becoming senescent could be one reason why they lose migratory potency, electrotaxis, and osteogenic potential. Recently, Siddappa et al. (2007) reported that serially passaged human MSCs showed low osteogenic potential and reduced proliferation potential with cells becoming senescent at late passage. Our findings show that cell electrotaxis is passage-dependent with higher passages of MSCs showing lower directedness and migration rate, and this appears to be related to cell-intrinsic factors including cell senescence. 


\section{Clinical relevance of EFs to bone regeneration and repair}

DC EFs exist in vivo and have profound influences on cell migration, orientation, and proliferation (McCaig et al., 2005; Nuccitelli, 2003; Zhao et al., 2006). Disrupting the EFs impairs development and wound healing (Hotary and Robinson, 1992; McCaig et al., 2005). Endogenous EFs take place at sites of bone fracture and therefore BMMSCs, commonly regarded as important players in bone regeneration, are likely to experience such EFs. Studies have shown the occurrence of: 1) electric potentials in stressed feline bone which generated a negative potential in the area of compression (Bassett and Becker, 1962), and 2) inward endogenous ionic current densities in damaged mouse bone, which ranged from $\sim 5$ to $129 \mu \mathrm{A} /$ $\mathrm{cm}^{2}$ (Borgens, 1984). Based on existing data, a model supports that the wound site of bone would be the anode of the endogenous EFs (McCaig et al., 2005). Our findings of MSC migration towards the anode would be in keeping with this model. However, whether those endogenous EFs have any effect on migration of MSCs in vivo is yet to be determined.

In orthopaedics, the clinical application of EFs in fracture healing and spinal fusion has been reported (Brighton et al., 1981; Brighton and Pollack, 1985; Dejardin et al., 2001; Gan and Glazer, 2006; Hodges et al., 2003; Lavine and Grodzinsky, 1987; Nelson et al., 2003). For the application of DC EFs, the amount of current applied that produces osteogenesis is between 5 and 20 $\mu \mathrm{A}$ (Brighton et al., 1981; Hodges et al., 2003; Nelson et al., 2003). The relationship between current and the electrical field is governed by Ohm's law: $E=\mathrm{J} . \rho$, where $E$ is the $E F(V / c m), J$ is the current density (in $\mathrm{A} / \mathrm{cm}^{2}$ ), and $\rho$ is the resistivity $(\Omega \mathrm{cm})$ (see McCaig et al., 2005). The resistivity of rabbit femurs is $\sim 8$ to $500 \mathrm{~K} \Omega \mathrm{cm}$ (Liboff $e$ t al., 1975; Singh and Saha, 1984). Thus, assuming that this range of resistivities is representative of the human tissue, the voltage of clinically applied EFs across the injury is $\sim 16$ to $1,000 \mathrm{mV} / \mathrm{mm}$; similarly, the endogenous wound current in mouse bone would generate an EF between 4 to $6,450 \mathrm{mV} / \mathrm{mm}$. Therefore, the threshold of EF strength effective in this study $(25 \mathrm{mV} / \mathrm{mm})$ is at the low end of both endogenous wound-induced EFs and of clinically applied EFs.

It has to be noted that, clinically, for fracture healing or spinal fusion the cathode is usually placed in the injury site while the anode is placed in the soft tissue away from the injury (Brighton et al., 1981; Brighton and Pollack, 1985; Dejardin et al., 2001; Gan and Glazer, 2006; Hodges et al., 2003; Lavine and Grodzinsky, 1987; Nelson et al., 2003). A recent study that attempted to identify the mode of action of DC EF treatment with the cathode implanted at the wound site reported up-regulated gene expression of the osteoinductive bone morphogenetic proteins BMP-2, -6, and -7 (Fredericks et al., 2007). While EF application seems to promote bone formation and repair, so far no study has addressed the effects of EF application on cell migration in vivo. Although our in vitro findings cannot be extrapolated to an in vivo setting, it is tempting to speculate that a customised biphasic EF treatment at the bone repair site that switches polarity from a brief initial anodal attraction of MSCs to a sustained cathodal bone stimulation could result in enhanced and a more effective repair outcome. In addition, DC EFs may be utilised to standardise bone tissue engineering approaches via spatial and temporal controls of cell migration into 3D scaffolds to generate bone substitutes. Thus, our findings provide a new perspective for the clinical application of DC EFs in human bone regeneration and repair.

In conclusion, small physiological DC EFs almost doubled the migration rate and induced robust directional migration of human bone marrow-derived MSCs towards the anode (positive electrode). This is a primary response of the MSCs and did not require any other cell type. Human bone marrow MSCs are of great potential in tissue engineering and regenerative therapy, and our data indicate that applied EFs of a similar and a greater magnitude to naturally occurring (wound-induced) EFs could be used to control homing of human bone marrow-derived MSCs to wounds in general and to injury sites in bone. Our findings encourage the development of a technique for application of EFs in vivo to guide migration of bone marrow MSCs in bone regeneration and healing therapy.

\section{Acknowledgments}

This work was supported by the Technology Strategy Board and the Engineering and Physical Sciences Research Council (Grant number: TS/G000786/1). The Technology Strategy Board is a business-led executive non-departmental public body, established by the government. Its role is to promote and support research into, and development and exploitation of, technology and innovation for the benefit of UK business, in order to increase economic growth and improve the quality of life. It is sponsored by the Department for Business, Innovation and Skills (BIS). For further information please visit www.innovateuk.org. We are grateful to Professor Min Zhao (University of California, Davis) for his invaluable assistance. We also thank Dr Chaman Chander (ApaTech Ltd) and Mr Hans Steuten (B1 Medical Ltd) for their critical review of the manuscript.

\section{References}

Aaron RK, Ciombor DM, Simon BJ (2004) Treatment of nonunions with electric and electromagnetic fields. Clin Orthop Relat Res 419: 21-29.

Barker AT, Jaffe LF, Vanable Jr JW (1982) The glabrous epidermis of cavies contains a powerful battery. Am J Physiol 242: R358-R366.

Bassett CA, Becker RO (1962) Generation of electric potentials by bone in response to mechanical stress. Science 137: 1063-1064.

Bassett CA, Pawluk RJ, Becker RO (1964) Effects of electric currents on bone in vivo. Nature 204: 652-654.

Bianco P, Robey PG (2001) Stem cells in tissue engineering. Nature 414: 118-121.

Borgens RB (1984) Endogenous ionic currents traverse intact and damaged bone. Science 225: 478-482. 
Brighton CT, Pollack SR (1985) Treatment of recalcitrant non-union with a capacitively coupled electrical field. A preliminary report. J Bone Joint Surg Am 67: 577-585.

Brighton CT, Black J, Friedenberg ZB, Esterhai JL, Day LJ, Connolly JF (1981) A multicenter study of the treatment of non-union with constant direct current. J Bone Joint Surg Am 63: 2-13.

Chang PC, Sulik GI, Soong HK, Parkinson WC (1996) Galvanotropic and galvanotaxic responses of corneal endothelial cells. J Formos Med Assoc 95: 623-627.

Chao PH, Roy R, Mauck RL, Liu W, Valhmu WB, Hung CT (2000) Chondrocyte translocation response to direct current electric fields. J Biomech Eng 122: 261-267.

Chiang M, Robinson KR, Vanable Jr JW (1992) Electrical fields in the vicinity of epithelial wounds in the isolated bovine eye. Exp Eye Res 54: 999-1003.

De Bari C, Dell'Accio F, Luyten FP (2001a) Human periosteum-derived cells maintain phenotypic stability and chondrogenic potential throughout expansion regardless of donor age. Arthritis Rheum 44: 85-95.

De Bari C, Dell'Accio F, Tylzanowski P, Luyten FP (2001b) Multipotent mesenchymal stem cells from adult human synovial membrane. Arthritis Rheum 44: 19281942.

De Bari C, Dell'Accio F, Vandenabeele F, Vermeesch JR, Raymackers JM, Luyten FP (2003) Skeletal muscle repair by adult human mesenchymal stem cells from synovial membrane. J Cell Biol 160: 909-918.

De Bari C, Dell'Accio F, Luyten FP (2004) Failure of in vitro-differentiated mesenchymal stem cells from the synovial membrane to form ectopic stable cartilage in vivo. Arthritis Rheum 50: 142-150.

De Bari C, Dell'Accio F, Vanlauwe J, Eyckmans J, Khan IM, Archer CW, Jones EA, McGonagle D, Mitsiadis TA, Pitzalis C, Luyten FP (2006) Mesenchymal multipotency of adult human periosteal cells demonstrated by single-cell lineage analysis. Arthritis Rheum 54: 1209-1221.

Dejardin LM, Kahanovitz N, Arnoczky SP, Simon BJ (2001) The effect of varied electrical current densities on lumbarspinal fusions in dogs. Spine J 1: 341-347.

Dominici M, Le Blanc K, Mueller I, Slaper-Cortenbach I, Marini F, Krause D, Deans R, Keating A, Prockop D, Horwitz E (2006) Minimal criteria for defining multipotent mesenchymal stromal cells. The International Society for Cellular Therapy position statement. Cytotherapy 8: 315 317.

Fernandez-Tresguerres-Hernandez-Gil I, AloberaGracia MA, del-Canto-Pingarron M, Blanco-Jerez L (2006) Physiological bases of bone regeneration II. The remodeling process. Med Oral Patol Oral Cir Bucal 11: E151-E157.

Ferrier J, Ross SM, Kanehisa J, Aubin JE (1986) Osteoclasts and osteoblasts migrate in opposite directions in response to a constant electrical field. J Cell Physiol 129: 283-288.

Fitzsimmons RJ, Farley J, Adey WR, Baylink DJ (1986) Embryonic bone matrix formation is increased after exposure to a low-amplitude capacitively coupled electric field, in vitro. Biochim Biophys Acta 882: 51-56.
Fong EL, Chan CK, Goodman SB (2011) Stem cell homing in musculoskeletal injury. Biomaterials 32: 395409.

Foulds IS, Barker AT (1983) Human skin battery potentials and their possible role in wound healing. Br J Dermatol 109: 515-522.

Fredericks DC, Smucker J, Petersen EB, Bobst JA, Gan JC, Simon BJ, Glazer P (2007) Effects of direct current electrical stimulation on gene expression of osteopromotive factors in a posterolateral spinal fusion model. Spine 32: 174-181.

Gan JC, Glazer PA (2006) Electrical stimulation therapies for spinal fusions: current concepts. Eur Spine J 15: 1301-1311.

Granero-Molto F, Weis JA, Miga MI, Landis B, Myers TJ, O'Rear L, Longobardi L, Jansen ED, Mortlock DP, Spagnoli A (2009) Regenerative effects of transplanted mesenchymal stem cells in fracture healing. Stem Cells 27: 1887-1898.

Hammerick KE, James AW, Huang Z, Prinz FB, Longaker MT (2010) Pulsed direct current electric fields enhance osteogenesis in adipose-derived stromal cells. Tissue Eng Part A 16: 917-931.

Hammerton RW, Krzeminski KA, Mays RW, Ryan TA, Wollner DA, Nelson WJ (1991) Mechanism for regulating cell surface distribution of $\mathrm{Na}+, \mathrm{K}(+)$-ATPase in polarized epithelial cells. Science 254: 847-850.

Hodges SD, Eck JC, Humphreys SC (2003) Use of electrical bone stimulation in spinal fusion. $\mathrm{J}$ Am Acad Orthop Surg 11: 81-88.

Hotary KB, Robinson KR (1992) Evidence of a role for endogenous electrical fields in chick embryo development. Development 114: 985-996.

Isaacson BM, Bloebaum RD (2010) Bone bioelectricity: what have we learned in the past 160 years? J Biomed Mater Res A 95: 1270-1279.

Karystinou A, Dell'Accio F, Kurth TB, Wackerhage H, Khan IM, Archer CW, Jones EA, Mitsiadis TA, De Bari C (2009) Distinct mesenchymal progenitor cell subsets in the adult human synovium. Rheumatology 48: 1057-1064.

Lavine LS, Grodzinsky AJ (1987) Electrical stimulation of repair of bone. J Bone Joint Surg Am 69: 626-630.

Levin MH, Verkman AS (2005) CFTR-regulated chloride transport at the ocular surface in living mice measured by potential differences. Invest Ophthalmol Vis Sci 46: 1428-1434.

Levin MH, Kim JK, Hu J, Verkman AS (2006) Potential difference measurements of ocular surface $\mathrm{Na}+$ absorption analyzed using an electrokinetic model. Invest Ophthalmol Vis Sci 47: 306-316.

Li X, Kolega J (2002) Effects of direct current electric fields on cell migration and actin filament distribution in bovine vascular endothelial cells. J Vasc Res 39: 391-404.

Liboff AR, Rinaldi RA, Lavine LS, Shamos MH (1975) On electrical condution in living bone. Clin Orthop Relat Res 106: 330-335.

Mauney J, Olsen BR, Volloch V (2010) Matrix remodeling as stem cell recruitment event: a novel in vitro model for homing of human bone marrow stromal cells to the site of injury shows crucial role of extracellular collagen matrix. Matrix Biol 29: 657-663. 
McCaig CD, Rajnicek AM, Song B, Zhao M (2005) Controlling cell behavior electrically: current views and future potential. Physiol Rev 85: 943-978.

McCaig CD, Song B, Rajnicek AM (2009) Electrical dimensions in cell science. J Cell Sci 122: 4267-4276.

Miller RJ, Banisadr G, Bhattacharyya BJ (2008) CXCR4 signaling in the regulation of stem cell migration and development. J Neuroimmunol 198: 31-38.

Nelson FR, Brighton CT, Ryaby J, Simon BJ, Nielson JH, Lorich DG, Bolander M, Seelig J (2003) Use of physical forces in bone healing. J Am Acad Orthop Surg 11: $344-354$.

Nuccitelli R (2003) A role for endogenous electric fields in wound healing. Curr Top Dev Biol 58: 1-26.

Ozkucur N, Monsees TK, Perike S, Do HQ, Funk RH (2009) Local calcium elevation and cell elongation initiate guided motility in electrically stimulated osteoblast-like cells. PLoS One 4: e6131.

Pittenger MF, Mackay AM, Beck SC, Jaiswal RK, Douglas R, Mosca JD, Moorman MA, Simonetti DW, Craig S, Marshak DR (1999) Multilineage potential of adult human mesenchymal stem cells. Science 284: 143-147.

Reichert JC, Woodruff MA, Friis T, Quent VM, Gronthos S, Duda GN, Schutz MA, Hutmacher DW (2010) Ovine bone- and marrow-derived progenitor cells and their potential for scaffold-based bonetissue engineering applications in vitro and in vivo. J Tissue Eng Regen Med 4: $565-576$.

Reichert JC, Wullschleger ME, Cipitria A, Lienau J, Cheng TK, Schutz MA, Duda GN, Noth U, Eulert J, Hutmacher DW (2011) Custom-made composite scaffolds for segmental defect repair in long bones. Int Orthop 35: 1229-1236.

Reid B, Song B, McCaig CD, Zhao M (2005) Wound healing in rat cornea: the role of electric currents. FASEB J 19: 379-386.

Robinson KR (1985) The responses of cells to electrical fields: a review. J Cell Biol 101: 2023-2027.

Robinson KR, Messerli MA (2003) Left/right, up/ down: the role of endogenous electrical fields as directional signals in development, repair and invasion. Bioessays 25: 759-766.

Siddappa R, Licht R, van Blitterswijk C, de Boer J (2007) Donor variation and loss of multipotency during in vitro expansion of human mesenchymal stem cells for bone tissue engineering. J Orthop Res 25: 1029-1041.

Singh S, Saha S (1984) Electrical properties of bone. A review. Clin Orthop Relat Res 186: 249-271.

Song B, Gu Y, Pu J, Reid B, Zhao Z, Zhao M (2007) Application of direct current electric fields to cells and tissues in vitro and modulation of wound electric field in vivo. Nat Protoc 2: 1479-1489.

Song M, Kim YJ, Kim YH, Roh J, Kim SU, Yoon BW (2010) Using a neodymium magnet to target delivery of ferumoxide-labeled human neural stem cells in a rat model of focal cerebral ischemia. Hum Gene Ther 21: 603-610.

Suzuki T, Mandai M, Akimoto M, Yoshimura N, Takahashi M (2006) The simultaneous treatment of MMP-2 stimulants in retinal transplantation enhances grafted cell migration into the host retina. Stem Cells 24: 2406-2411.
Trollinger DR, Isseroff RR, Nuccitelli R (2002) Calcium channel blockers inhibit galvanotaxis in human keratinocytes. J Cell Physiol 193: 1-9.

Welsh MJ (1987) Electrolyte transport by airway epithelia. Physiol Rev 67: 1143-1184.

Yao L, McCaig CD, Zhao M (2009) Electrical signals polarize neuronal organelles, direct neuron migration, and orient cell division. Hippocampus 19: 855-868.

Zhang J, Calafiore M, Zeng Q, Zhang X, Huang Y, Li RA, Deng W, Zhao M (2011) Electrically Guiding Migration of Human Induced Pluripotent Stem Cells. Stem Cell Rev DOI: 10.1007/s12015-011-9247-5.

Zhao M, Agius-Fernandez A, Forrester JV, McCaig CD (1996) Orientation and directed migration of cultured corneal epithelial cells in small electric fields are serum dependent. J Cell Sci 109: 1405-1414.

Zhao M, Dick A, Forrester JV, McCaig CD (1999) Electric field-directed cell motility involves up-regulated expression and asymmetric redistribution of the epidermal growth factor receptors and is enhanced by fibronectin and laminin. Mol Biol Cell 10: 1259-1276.

Zhao M, Bai H, Wang E, Forrester JV, McCaig CD (2004) Electrical stimulation directly induces preangiogenic responses in vascular endothelial cells by signaling through VEGF receptors. J Cell Sci 117: 397-405.

Zhao M, Song B, Pu J, Wada T, Reid B, Tai G, Wang F, Guo A, Walczysko P, Gu Y, Sasaki T, Suzuki A, Forrester JV, Bourne HR, Devreotes PN, McCaig CD, Penninger JM (2006) Electrical signals control wound healing through phosphatidylinositol-3-OH kinase-gamma and PTEN. Nature 442: 457-460.

Zhao Z, Qin L, Reid B, Pu J, Hara T, Zhao M (2011) Directing migration of endothelial progenitor cells with applied DC electric fields. Stem Cell Research 8: 38-48.

Zuk PA, Zhu M, Ashjian P, De Ugarte DA, Huang JI, Mizuno H, Alfonso ZC, Fraser JK, Benhaim P, Hedrick MH (2002) Human adipose tissue is a source of multipotent stem cells. Mol Biol Cell 13: 4279-4295.

\section{Discussion with Reviewers}

Reviewer I: How do the authors envision the application of their findings clinically, as applied EFs are already being used for bone fracture healing and for spinal fusion?

Authors: Our in vitro proof-of-concept study provides evidence that MSCs migrate in response to EFs. At present, it would be premature to place our findings into a clinical perspective but it is tempting to speculate a twofold application: 1) to direct and enhance migration of endogenous bone marrow MSCs to the site of fracture in vivo; 2) to standardise bone tissue engineering approaches via spatial and temporal controls of MSC migration into 3D scaffolds for the generation of bone substitutes.

Reviewer I: The current findings of anodal migration of cells are not consistent with cathodal healing of bone that is observed clinically (albeit the time frames of the two are very different).

Authors: Our findings may be in apparent discrepancy with the current application of EFs in vivo with the placement 
of the cathode at the site of healing. However, while prolonged cathodal stimulation seems to promote bone formation, possibly as a result of EF-induced up-regulation of osteoinductive BMPs at the wound site, as described by Fredericks et al. (2007), so far no study has addressed the effects of EF application on cell migration in vivo, which is likely to be an early response. Although our in vitro findings cannot be extrapolated to an in vivo setting, it is possible that a biphasic EF treatment at the bone repair site that switches polarity from a brief initial anodal attraction of MSCs to a sustained cathodal bone stimulation could result in a more effective repair outcome.
Reviewer II: At the rate of cell migration detected, which is about $29 \mathrm{~mm} / \mathrm{month}$, how do the authors think these results might be applied clinically?

Authors: The migration speed observed in our in vitro study may not appear clinically relevant. However, the in vivo scenario is far more complex, with speed of migration being affected by several other factors, such as gradients of chemokines and other signalling molecules, receptors expressed on MSCs, interactions with various cell types and surrounding extracellular matrix. In vivo studies will be necessary to investigate the effects and mechanisms of EF application on MSC migration during bone regeneration and repair. 